\title{
AZ ÚJONNAN IPAROSODÓ DÉLKELET-ÁZSIAI ORSZÁGOK VILÁGGAZDASÁGI SZEREPKÖRÉNEK ALAKULÁSA 1970-1993 KÖZÖTT ${ }^{1}$
}

\author{
(The evolution of the role of the newly industrialised south-east Asian \\ countries in the world economy in 1970-1993)
}

\section{SZEGEDI GABRIELLA}

\section{Bevezetés}

A Római Klub az 1972-ben publikált “A növekedés korlátai” c. jelentése után a 90-es évek elején ủjra vizsgálta, elemezte az ott felvetett gazdasági, környezeti problémákat, az azóta bekövetkezett változásokat. Az 1991-ben megjelent tanulmány "geostratégiai változásként" három ipari és kereskedelmi csoportosulás, tömb létrejöttét, fejlődését emelte ki, ezek: az Észak-amerikai tömb, az EK országai, Japán és a NIE+ASEAN országok voltak (King-Schneider 1991).

Külön kiemelték, hogy a gyors technológiai változásokra és azok alkalmazásaira legrugalmasabban és leghatékonyabban - az eltelt húsz év alatt - Japán, és a NIE-NIC ${ }^{2}$, valamint az $\mathrm{ASEAN}^{3}$ országok reagáltak.

Délkelet-ázsiai térségen tanulmányunkban nyolc újonnan országot: Hongkongot, DélKoreát, Szingapúrt, Tajvant ${ }^{4}$, a Fülöp-szigeteket, Indonéziát, Malajziát és Thaiföldet értjük.

Jelen tanulmány célja, hogy a vizsgált országok világgazdasági szerepének alakulását, világkereskedelmi fontosságuk növekedését elemezze; tendenciákat, általános jellegzetességeket és megfigyelhető kủlönbségeket keresve 1970 és 1993 között.

A XX. század második felétől a világgazdaságban tapasztalható általános tendenciák egyre nyilvánvalóbbá tették, hogy az egyes országok világgazdasági szerepkörét, gazdasági növekedését az "exogén" tényezőkhöz, a világgazdasági folyamatokhoz való alkalmazkodóképesség fogja megszabni.

A globális kihíváshoz való alkalmazkodást, illeszkedést a fejlődỏ országok többsége számára a 70-es évek közepétől kezdve igen megnehezítette - az adósságtörlesztésen kívül - az a tény, hogy a gazdaság, a termelés növekedése a 80-as éveket követően döntóen már nem a beruházások, vagy a foglalkoztatottság növeléséból, a természeti erőforrások kiaknázásából, hanem a tudományos eredmények felhasználásából származott (Kádár 1985).

\section{A külkereskedelmi áruszerkezet irányultságának változása; a gazdasági szerkezet átalakulása}

A világ legdinamikusabb gazdasági növekedésủ térségét (Japánt és a NIC országokat együttesen) napjainkban már joggal tekinthetjük egy új regionális világgazdasági központnak. Ez a gyors gazdasági növekedés (Hernádi 1985) az 1960-as években kezdődött, térben és időben kiszélesedő folyamatnak köszönhető, melynek kiindulópontja, 
irányítója kezdetben Japán volt. A II. világhảborút követő japán gazdasági csoda hatása szinte „tovagyürüzött" a térségben - egyik legjobb példájaként a regionális indukció elméletének -; a 60-70-es években Hongkongban, Dél-Koreában, Tajvanon, Szingapúrban (ún. NIC I. országok), a 80-as évektöl pedig második hullámként Indonéziában, Malajziában a Fülöp-szigeteken és Thaiföldön (ún. NIC II. országok) volt észlelhetö. A gyors növekedési ütem összefüggött a világpiacon elért sikerekkel, a világkereskedelmi fontosság növekedésével, amihez a legtöbb országban gazdaságpolitikai váltásra, a világgazdasági tendenciákhoz való alkalmazkodási készségre, gyors reagálásra volt szükség.

Simai M. (1990) szerint a világgazdaság alakulása szempontjából fontos országokban három, a globális és versengó világpiaci viszonyokra épülő "uralkodó modell" jelent meg:

1. amerikai pluralista piacgazdasági modell (fogyasztásorientált, rövid távú szemlélet, versenyképes pénzpiac, rugalmasság, minimális állami szabályozás, versengő magángazdaság)

2. nyugat-európai modell (szociális piacgazdaság, intenzív kölcsönhatások az állam és a társadalmi partnerek között)

3. korporációs Japán modell (hosszú távú szemlélet, sokoldalú együttműködés a kormány és a vállalatok között, gyors és hatékony reagálás a nemzetközi feltételek változásaira).

A japán modellt utánzó délkelet-ázsiai országok világgazdasági fontosságának, exportáru-szerkezet irányultságát vizsgálva a következỏ kérdésekre kerestük a válaszokat:

- Hogyan változott meg az országok világgazdasági szerepköre, fontossága 1970-1993 között; a gazdasági növekedés együtt járt-e a külkereskedelem növekedésével, az exportszerkezet átalakulásával?

- A gazdaságpolitikai változások által indukált gazdaságszerkezeti átalakulás hogyan változott meg, és mennyiben igazodott a világgazdasági igényekhez?

- Megállapíthatók-e általános tendenciák a NIC I. és NIC II. csoportokhoz tartozó országoknál a világgazdasági kihívásra adott gazdasági válaszok (export és GDP szektor megoszlás) elemzése alapján?

\section{Az export növekedése a NIC országokban}

Számításaink szerint ${ }^{5}$ (a vizsgált időszakban) a világkereskedelem általános jelensége volt, hogy 1970-től az 1980-as évek elejéig folyamatosan nőtt (17,65\%-ról, 33\%-ra) a fejlödő országok részesedése a világ összes exportjából. A nyolcvanas évek közepétöl a köolaj árának csőkkenését követöen ez a részesedés visszaesett (1986-ban 25,2\% a mélypont) majd fokozatosan a 90-es évekre újból elérte a 30\%-ot, ami már nem az energiaárak emelkedéséböl, hanem egyes fejlödö országok világkereskedelmi részesedésének jelentős nơvekedéséből származott.

A fejlődő országok közül legdinamikusabban a NIC országok növelték a részesedésüket, hiszen amíg 1970-ben a világ összes exportjának 3,06\%-a, a fejlödö országok összkivitelének 17,37\%-a származott a délkelet-ázsiai újonnan iparosodott országokból, addig 1993-ban már a világexport 13,83\%-át, a fejlődő országok összkivitelének pedig 44,03\%-át adták, miközben a világexportból való részesedésüket a NIC I. csoport országai megötszörözték, a NIC II. országok pedig 2,4-szeresére növelték.

A világ és a vizsgált országok összes exportjának évi átlagos százalékos növekedési ráta értékeit - három időintervallumra bontva - az 1. táblázatban foglaltuk össze. Az 1970-80as évek között a 19,55\%-os világexport növekedési ráta döntően a fejlödő országok gyors 
kivitel-növekedéséből (olajexportőrök) adódott. A NIC országok közül a töretlen gazdasági növekedésü Dél-Korea mellett Szingapúr (olajreexport) és Indonézia (olajexport) rátája volt a legmagasabb.

\section{TÁBLÁZAT}

Az összes kivitel évi átlagos százalékos növekedési rátája

(The average share of growth in the export sector by years)

\begin{tabular}{|l|c|c|c|}
\hline & $1970-1993$ & $1970-1980$ & $1980-1990$ \\
\hline világexport & 11.31 & 19.55 & 7.03 \\
\hline fejlett országok & 11.01 & 18.62 & 7.39 \\
\hline fejlödő országok & 14.14 & 27.14 & 6.62 \\
\hline Hongkong & 18.91 & 22.87 & 21.21 \\
\hline Dél-Korea & 22.17 & 35.56 & 16.92 \\
\hline Szingapúr & 18.29 & 28.71 & 14.35 \\
\hline Indonézia & 16.46 & 34.77 & 5.34 \\
\hline Malajzia & 15.35 & 22.07 & 13.77 \\
\hline Fülop-szigetek & 10.57 & 17.86 & 6.91 \\
\hline Thaiföld & 18.77 & 24.79 & 19.03 \\
\hline
\end{tabular}

Forrás: Direction of Trade Stat. Yearbook (1970-1994)

Az általános világgazdasági recesszió, majd a köolajár-csökkenés hatására a világexport és a fejlett országok évi átlagos százalékos növekedési rátája több, mint a felére esett vissza (7,03\%), a fejlödöknél pedig a negyedére csökkent (6,62\%) 1980 és 1990 között, az 1970-1980 közötti rátához képest. Az újonnan iparosodó délkelet-ázsiai országok közül legdrasztikusabban Indonéziában csökkent (a hetedére!) a kivitel átlagos, százalékos növekedése, míg a többi országnál a világexporthoz hasonlóan a felére csökkent. Feltủnỏ, hogy a NIC országok export növekedési rátája - Indonézia és Fülöp-szigetek kivételével kétszer, háromszor nagyobb volt a 80-as években, mint amekkora a fejlett ill. fejlödö országok átlagos növekedése. Balassa B. (1990) szerint ez döntỏen annak volt köszönhetö, hogy a délkelet-ázsiai országok többsége már az 1960, 1970-es évektöl kezdve (az esetenkénti importhelyettesités kezdeti szakaszát követően) a kifelé fordulás gazdaságpolitikáját támogatta.

A NIC I. csoport országaiban már a 60 -as évektöl az exportősztönzés volt a gazdasági szerkezet átalakulásának legfontosabb hajtóereje; melynek lényege, hogy versenykényszert teremt a gazdaságban, elősegíti a komparatív előnyök kihasználását, és ösztönözve az ágazaton belüli specializálódást, elősegíti a termelés nemzetközi megosztásába való bekapcsolódását.

Ennek sikerét - miközben az egy före jutó export értéke mindhárom országban folyamatosan nőtt - nemcsak az elözőekben már tárgyalt gyors gazdasági növekedés, hanem a világkereskedelemben való egyre nagyobb arányú részvétel is igazolta.

A 80-as évek általános világgazdasági recesszióját az a két leginkább exportra utalt ország, Hongkong és Szingapúr érezte meg, ahol az exportkoefficiens ${ }^{6}$ értéke (Szingapúrnál 1973 óta, Hongkongnál 1987 után) meghaladta a 100\%-ot, ami igen jelentős reexport tevékenységre utal. Dél-Korea stabil export/fö növekedéséhez a 90-es évek elejéig fokozatosan növekvő exportkoefficiens párosult (1970: 10,51\%, 1989: 
33,07\%); érdekes momentum, hogy 1990-től viszont fokozatosan csökken az export szerepe a GNP elóállításában (1993: 24,7\%), hasonlóan pl. Japánhoz.

Ennek egyik okaként említhetjük, hogy ezen országok már a 70-es évek végétöl a térség fontos tőkeexportálói lettek, másrészről pedig a multinacionális vállalatok egyik leggyümölcsőzőbb befektetési területeivé váltak.

Mivel mind a három országban - a GNP/fö értékekhez hasonlóan - jelentősen növekedett az egy fỏre jutó export értéke a vizsgált 23 évben, ezért a két változó erős összefüggését feltételezve korrelációs vizsgálatot végeztünk.

A legszorosabb összefüggést az export/fö növekedésének GNP/fö növelö hatását bizonyítva Hongkongnál $(\mathrm{r}=0,983)$ és Szingapúrnál $(\mathrm{r}=0,984)$ tapasztaltuk. Figyelemreméltó, hogy amíg Hongkongnál és Szingapúrnál az export egységnyi növekedése 0,7 ill. 0,6 egységgel növelte a GNP/fö értékét, addig Dél-Koreában $(\mathrm{r}=0,972)$ az export/fö dollárnyi növekedése 3,5 dollárral növelte az egy före jutó bruttó nemzeti termék értékét. Az előzőekben már megemlítettük, hogy Dél-Koreában Japánhoz hasonlóan a 90-es évektől folyamatosan csökkent az exportkoefficiens értéke. Most ismét a Japán példára kell hivatkoznunk, hiszen a térség vezető államában (ahol az exportkoefficiens értéke az utóbbi években 10-15\% körül mozgott) az egységnyi exportnövekedés 10,7 dollár GNP/fö növekedéssel járt együitt 1970 és 1993 között.

A NIC II. csoportjához tartozó országok többségénél az ENSZ és a Világbank támogatásával a gazdasági struktúra átalakitását az importhelyettesítő gazdaságpolitika bevezetésével, a mezőgazdaság fejlesztésével (Malajziában és Thaiföldön új földterületek müvelésbe vonásával, a Fülöp-szigeteken pedig a nagybirtokrendszer megszüntetésével), a beruházások növelésével és a humán töke kiaknázásával (oktatási ráforditások növelése) próbálták megvalósítani a 60 -as években. Ez a stratégia azonban korántsem váltotta be a hozzáfüzött reményeket. Az importhelyettesítés „eredményei" már a 70-es évektől sürgös változtatásokra késztették Malajzia és Thaiföld kormányát, míg a nagyobb belső piaccal rendelkező Indonéziában, ill. a Fülöp-szigeteken - Marcos elnök bukását követően - ez az átalakulási folyamat csak a 80 -as évek elején indult meg. Az előbb említett „eredmények” a következőkben foglalhatók össze (Balassa 1990):

- az importhelyettesítést választott országok feldolgozóipara elszakadt a világpiactól,

- a belső növekedés lehetőségeit rontották a belső piacon érvényesülő korlátozó tényezők, ami miatt a termelés növekedési folyamata lelassult,

- egyre magasabbá vált az importhelyettesítés költsége, ha olyan iparágban alkalmazták, ahol a tömegtermelés elónnyel járt volna.

Ezek alapján a befelé fordulás egy „koravén” ipari struktúrát alakított ki (KÁDÁR, 1985), elmaradott technikai háttérrel, gyenge minőségủ termékekkel és kis volumenủ nem kellöen szakosodott iparral. Ez a stratégia igy lényegében semmiféle lehetőséget nem biztosított ahhoz, hogy az egyes országok alkalmazkodva a világgazdaság kihivásaihoz bővíteni tudják világkereskedelmi szerepköruket. A NIC II. vonalához tartozó országoknál az egy före jutó export értékek változásánál markánsan elkülönült Malajzia és Thaifơld, valamint Indonézia és a Fülöp-szigetek növekedése. A legkimagaslóbb növekedést az a Malajzia produkálta, ahol a meglévő nyersanyag feldolgozására alapozott exportorientált gazdaságpolitika már a 70-es évek elejétöl éreztette hatását. Kis megtorpanásokkal (a világgazdasági recessziók, és a kőolajár csökkenése miatt is) az export/fö értéke folyamatosan nőtt (legnagyobb ütemben 1986 óta) párhuzamosan az exportkoefficiens 
értékével (1970: 42\%, 1993: 78,8\%); ezek a tendenciák egyedülállóak a második csoport országai között.

Thaiföldön - ahol a 70-es évek második felétỏl szintén a kifelé fordulás politikáját választották - a hatás, az export/fó értékek növekedése a 80-as évek második felétől érzékelhető. A 70-es, 80-as években még olcsó munkaerő megélénkítette a gazdasági életet, vonzotta a külföldi befektetőket (pl. a Toyota, Honda, Volvo, Chrysler, Ford autók összeszerelö üzemei is ekkor épültek), így nem csoda, hogy az exportkoefficiens értéke, ami 1970-ben 9,8\% volt 1993-ra már elérte a 30\%-ot. A két, csak az 1980-as évek második felétől gazdasági stratégiát váltó Indonézia és a Fülöp-szigetek export/fö és exportkoefficiens ${ }^{7}$ értékei a 80-as évek végétől mutatnak lassú és fokozatos emelkedést, de a növekedési ütem meg sem közelíti az elöbbiekben említett két országét.

Az export és a GNP egy före jutó értékei között a legszorosabb összefüggés Malajziában és Thaiföldön van $(\mathrm{r}=0,958, \mathrm{r}=0,982)$, bár Indonézia és a Fülöp-szigetek sem sokkal maradt el $(r=0,953, r=0,937)$ ezen értékektöl. A NIC I. csoport országainál már megállapítottuk, hogy a gazdaság exportra való ráutaltságának alacsonyabb százalékos értékénél egységnyi export/fő növekedés nagyobb GNP/fö növekedésével járt együtt. Ez a NIC II. országainál is igaz. Míg Indonéziában és a Fülöp-szigeteken - ahol az exportkoefficiens értéke 30\% alatt volt - 3,62 ill. 5,12 egységgel nởtt a GNP/fö értéke az export/fö egységnyi növekedésével párhuzamosan, addig Malajziában és Thaiföldön (exportkoefficiens 78\% ill. 31\%) ez az érték 1,16 valamint 2,88 dollár volt 1970 és 1993 között.

A délkelet-ázsiai térség kiemelkedó gazdasági növekedésének fö oka a gyors gazdasági struktúraváltás, a világgazdasági folyamatokhoz való gyors alkalmazkodóképesség (Kwan 1994). A szerző emellett fontos külsỏ hatásként említi, hogy az USA gazdasági erejének relatív visszaesése, valamint a 80-as évektöl az USA és az ázsiai országok között kialakult kereskedelmi feszültség egyrészt arra ösztönözték az országokat, hogy exportszerkezetüket diverzifikálják, másrészt pedig, hogy kereskedjenek többet egymás között. Ekkor vált az USA helyett Japán a térség legnagyobb befektetőjévé; a 80-as évek közepétől pedig már a NIC I. országok is felbukkantak, mint fontos tőkeberuházók a régióban, ami tovább növelte az intraregionális kereskedelmet.

\section{Az export szerkezeti összetételének és a GDP szektoronkénti megoszlásának változása a NIC országokban}

A NIC I. csoporthoz tartozó országok az 1960-70-es évektől a világgazdasági igényeket maximálisan figyelembevevó, azokhoz rugalmasan alkalmazkodó exportösżönzó gazdạságpolitikát alkalmaztak. A Japán érdekszférához tartozó országok a centrum ország példáfát követve dinamikusan növelték világkereskedelmi súlyukat, miközben exportszerkezetủk átalakult, diverzifikálódott. Ehhez az átalakuláshoz jelentõs tökére volt szükség. A 70-es években szinte szabályszerü harc folyt az országok között a külföldi befektetőkért, amelyből Szingapúr került ki gyỏztesen, hiszen a 80-as évek elejére a világ elsỏ számú beruházási területévé vált bár a tởbbi NIC I. ország is az első 15 között volt (Hernádi 1985).

Az országok exportszerkezetét az ENSZ SITC (0-9) besorolás, a gazdasági szerkezet átalakulását pedig az egyes szektorok GDP-ből való százalékos részesedése alapján vizsgáltuk ${ }^{8}$. 
A három NIC I. ország közül a Hoover-féle index alapján számított legnagyobb exportszerkezeti átalakulás Szingapúrban és Dél-Koreában következett be. (A Hoover-féle index a térbeli megoszlások időbeli változásának mérésére használt mutató $\mathrm{H}=\Sigma \mid \mathrm{a}_{1^{-}}$ $\mathrm{a}_{2 \mathrm{i}} \mid / 2$, ahol $\mathrm{a}_{1 \mathrm{i}}=\mathrm{az}$ i-edik területegység százalékos részesedése $a z \quad \mathrm{a}_{\mathrm{i}}$ adatsor összvolumenéből az első időpontban; $\mathrm{az}_{\mathrm{a}_{\mathrm{i}}}=$ ugyanezen érték a második időpontban.)

1970 és 1993 között Szingapúrban 54,48\%, Dél-Koreában 42,9\%, Hongkongban pedig „csak” 22,3\%-os volt az átrendezödés mértéke a SITC kategóriák között. Ez az átrendeződés döntően a 7-es kategória (gépgyártás, szállítóeszközök) térnyerését és ezzel párhuzamosan a 0-4 kategóriák százalékos részesedésének jelentös csökkenését jelentette, amit jól tükröz egyrészt az, hogy mind a három országban $20 \%$ fólötti volt a 7 -es kategória évi átlagos százalékos növekedési rátája (Hongkong: 24,1\%, Dél-Korea: 32,07\%, Szingapúr: 27,2\%); másrészt pedig az, hogy Szingapúrban az összes kivitel 58,29\%-a, Dél-Koreában 44,96\%-a, Hongkongban pedig 30,5\%-a származott ebböl a termékcsoportból $1993^{9}$-ban. A három ország általános jellegzetessége, hogy az export termékek majdnem 100\%-át a feldolgozott termékek (SITC 5,6,7,8) adták ${ }^{10}$, csak belső arányuk változott az idó során; miközben a 7-es kategória részesedése a 80-as évektöl ugrásszerúen, az 5-ös kategória pedig lassan növekedett, addig az 6-os, 8-as kategóriák százalékos részesedése csökkent, vagy stagnált (2. táblázat).

\section{TÁBLÁZAT}

A SITC 5,6,7,8 kategóriák százalékos részesedése az összes exportból a NIC I. és a NIC II. csoport országaiban 1970, 1993

(The share of SITC 5-8 categories of the whole export in NIC I. and II. countries, 1970, 1993)

\begin{tabular}{|l|c|c|c|c|c|c|c|c|}
\cline { 2 - 9 } \multicolumn{1}{c|}{} & \multicolumn{9}{c|}{1970} & \multicolumn{3}{c|}{1993} \\
\hline & 5 & 6 & 7 & 8 & 5 & 6 & 7 & 8 \\
\hline Hongkong & 3.99 & 19.99 & 11.37 & 57.71 & 5.03 & 16.74 & 30.56 & 41.69 \\
\hline Dél-Korea & 1.37 & 26.47 & 7.37 & 42.21 & 5.91 & 25.44 & 44.96 & 17.12 \\
\hline Szingapúr & 2.73 & 8.91 & 10.95 & 5.19 & 6.31 & 6.51 & 58.29 & 8.26 \\
\hline
\end{tabular}

\begin{tabular}{|l|c|c|c|c|c|c|c|c|c|c|}
\cline { 2 - 12 } \multicolumn{1}{c|}{} & \multicolumn{9}{c|}{1970} & \multicolumn{5}{c|}{1993} \\
\hline & 5 & 6 & 7 & 8 & 9 & 5 & 6 & 7 & 8 & 9 \\
\hline Indonézia & 0.5 & 1.1 & 0.3 & - & 0.2 & 2.2 & 26.4 & 5.9 & 18.9 & 0.5 \\
\hline Fülöp-szk & 0.5 & 6.2 & - & 0.8 & - & 2.2 & 7.1 & 18.6 & 15.5 & 35.7 \\
\hline Malajzia & 1.4 & 28.4 & 2.3 & 1.6 & 0.7 & 2.1 & 9.5 & 48.5 & 10.3 & 0.6 \\
\hline Thaiföld & 0.3 & 14.8 & 0.6 & 0.6 & 5.2 & 2.8 & 12.2 & 29.6 & 26.5 & 1.5 \\
\hline
\end{tabular}

Forrás: Saját számítás a Directorie of Trade Statistical Yearbook alapján (1970-1994)

A világgazdasági igényekhez való alkalmazkodás természetesen a gazdasági szerkezet jelentős átalakítását igényelte. A World Development Report adatait felhasználva az egyes szektorok (mezógazdaság, ipar, ezen belủl gyáripar, szolgáltatás) GDP-ból való százalékos részesedésének változását is megvizsgáltuk 1970-ben és 1993-ban.

A három ország közül Dél-Koreában és Szingapúrban hasonló gazdaságátalakulási folyamatok zajlottak. A mezógazdaság részesedése csökkent - bár Szingapúrban ez eredetileg sem képviselt magas százalékot -, az iparé ${ }^{11}$, ezen belül a gyáripar százalékos részesedése, valamint Dél-Koreában a tercier szektor részesedése is nőtt. Hongkongnál 
ezzel szemben a tercier szektor majd 80\%-os részesedése mellett az ipari termelés - ezen belül a gyáripar részesedése is - jelentősen csökkent.

A tercier szektor magas részesedése mind a két városállamban elsősorban - az elözőekben már említett - pénzügyi és kereskedelmi központ funkcióból adódik. DélKorea vezetése viszont fontosnak tartja stratégiai iparágak fejlesztését (pl. hajó-, autógyártás), amit az is igazol, hogy a XX. század végére az ország a világ legnagyobb ớt autógyártója közé kíván kerülni.

A NIC II. vonalához tartozó országok az exportösztönzỏ gazdaságpolitikát csak a 70-es évek közepe, vége felé alkalmazták (követve az első csoport országainak példáját); ennek az exportszerkezet átalakulására, irányultság-váltására tett hatása azonban - Indonézia kivételével - jelentősen meghaladta a NIC I. országok közötti legmagasabb Hoover-index értékét (Szingapúr: 54,48\%). A exportszerkezet legnagyobb mértékben a Fülöp-szigeteken és Malajziában rendeződött át (Hoover-index: 72,11\%, ill. 63,81\%) 1970 és 1993 között, míg Thaiföldön "csak" 57,78\%, Indonéziában pedig 51,97\% volt az átrendeződés mértéke a SITC kategóriák között.

A rendelkezésre álló adatok szerint a 0-4 (élelmiszer, ásványi- és fütỏanyag) árucsoport mind a négy ország exportjában rendkívül fontos szerepet játszott 1970-ben. Indonézia összes exportjának 97,5\%-át, a Fülöp-szigetek kivitelének 92,3\%-át ezek a kategóriák adták; Thaiföldön és Malajziában ez az érték $80 \%$ alatt maradt (77,9\% ill. 65,2\%). Ezen áruféleségek exportja összességében jelentősen visszaszorult 1993-ra, bár a két kőolajexportör (Indonézia és Malajzia) esetében a köolajexport, a Fülöp-szigetek és Thaiföld esetében pedig az élelmiszerexport még mindig jelentös volt ${ }^{12}$. A nyersanyag és élelmiszerexport csökkenésével párhuzamosan mind a négy országban - a kullföldi töke beruházásait ill. hitelfelvételt követően - jelentősen növekedett az 5,6,7,8,9-es árucsoportok részaránya a kivitelben.

$\mathrm{Az}$ adatok alapján itt is külön kiemelhetö Malajzia és Thaiföld, ahol a 7-es, 8-as kategóriák évi, átlagos százalékos növekedése volt a legnagyobb ill. Indonézia, ahol 6-os és 8-as kategóriák, valamint a Fulöp-szigetek, ahol a 7-es és 9-es kategóriák exportértéke növekedett a legnagyobb ütemben.

Már az évi átlagos százalékos növekedési ráta értékei is előre jelezték ( $11,2 \%$ és $54,6 \%$ között), hogy milyen jelentős változásokat indukált az exportszerkezetben a gazdaságpolitika megváltoztatása, az alkalmazkodási kényszer a megváltozott világgazdasági viszonyokhoz. A kivitel áruszerkezeti százalékos megoszlása azonban még szemléletesebbé teszi az 1970 és 1993 között lezajlott változásokat (2. táblázat).

A NIC II. vonalához tartozó országokat az export/fỏ értékek alapján már a korábbiakban is két jól elkülöníthető csoportra osztottuk. Ez az elkülönülés az exportszerkezet átalakulásában is megfigyelhetó volt. Amíg Malajziánál és Thaiföldnél - a NIC I. országokhoz hasonlóan - az 5,6,9-es kategóriák százalékos részesedése csökkent vagy stagnált, addig a 7-es kategória részesedése jelentősen növekedett (a 8-as kategóriával együtt, ebben eltértek a NIC I. országaitól).

Míg Malajziában az 1960-70-es években az export döntő részét az ón-, a kaucsuk-, és élelmiszerexport adta, addig a külföldi tőke beáramlását követően, ma már föként munkaerő-igényes elektronikai termékekkel ill. iparcikkekkel jelenik meg a világpiacon, amit az is tükröz, hogy Malajzia vált a 90-es évekre a térség legnagyobb munkaeröbefogadó országává (a másik három NIC II. ország viszont a térség legnagyobb munkaerỏ küldői közé tartozik). Thaiföld az 1960-70-es években föként, mint rizsexportör volt jelen a világpiacon. A kezdetben még olcsó munkaerőre építő külföldi tőke beáramlását 
követően - hasonlóképpen Malajziához - itt is az elektronikai termékek, iparcikkek gyártása mellett a szintén munkaerô-igényes textilipar fejlesztése került elötérbe. A 80-as évektöl viszont az emelkedő átlagbérek miatt már Thaiföldnek is az áll érdekében - mint, ahogy azt Japán, majd késỏbb a NIC I. országok is tették -, hogy olcsóbb, külfóldi munkaerōvel dolgoztasson (pl. Vietnamban ${ }^{13}$, Kínában), miközben a szakképzett munkaerőbázisára támaszkodva jelentős minőségi fejlesztést hajt végre.

$\mathrm{Az}$ exportszerkezet átalakulásának vizsgálatát követően a World Development Report adatait felhasználva a gazdasági szerkezet ágazati, százalékos részesedésének átalakulását is megvizsgáltuk. (Sajnos Malajziára csak 1970-es adatok álltak rendelkezésünkre, így a gazdasági szerkezet átalakulásának elemzéséből az ország kimaradt.) Thaifơldön - DélKoreához hasonlóan - a mezőgazdaság GDP-ből való részesedése csökkent (26\%-ról $10 \%$-ra), az iparé (25\%-ról 39\%-ra), a gyáriparé (16\%-ról $28 \%$-ra), a tercier szektoré (49\%-ról 51\%-ra) nött.

Indonéziában és a Fülöp-szigeteken a szinte nulláról indult 6,7,8-as (ill. a Fülöpszigeteknél még a 9-es kategória) kategóriák részesedése az összes kivitelből jelentősen növekedett 1970 és 1993 között. Bár Indonézia kivitelének majd 30\%-át még mindig a kőolaj adta 1993-ban, jelentősen növekedett a munkaerő-igényes 6-os, 8-as kategóriák részesedése is. A dél-koreai példát követve - ahol stratégiai iparágként kezelik pl. az autógyártást - Indonézia vezetői is csúcstechnológiát alkalmazó stratégiai iparág kifejlesztésére (repülógépgyártás) törekedtek, amihez együttesen sem volt elég az olajbevételekből származó pénz ill. a külföldi tőke megjelenése az országban. Az iparosítás kezdeti lépéseihez is hitelekre volt szükség, napjainkban Indonézia adósságállománya meghaladja a 100 milliárd dollárt.

A Fülöp-szigetek speciális helyzetéröl tanulmányunkban már többszoòr említést tettünk. A NIC II. csoport országai között itt volt az exportszerkezet átalakulása a legnagyobb mértékú (Hoover-index: 72,1\%). Ez döntően a 9-es kategória részesedésének növekedését jelentette. Amíg az 1970-es évek elején az export 80\%-át az élelmiszer és ásványi anyagok adták, addig 1993-ra a 7-es, 8-as, 9-es kategóriák együttesen 60\%-ban részesedtek a kivitelböl. Hasonlóképpen Indonéziához a Fülöp-szigeteken sem volt elég az exportbevétel növekedése ill. a külföldi töke az iparosításhoz, az ország hitelek felvételére kényszerült, melynek értéke 1994-re már meghaladta a 40 milliárd dollárt.

A GDP ágazati megoszlása, a gazdasági szerkezet átalakulása a többi országhoz hasonló képet mutat, jelentősen csökkent - bár 1993-ban még mindig 20\% körüli - a mezőgazdaság részesedése, szemben viszont a többi országgal a Fülöp-szigeteken nem az ipar (bár ennek a részesedése is nőtt), hanem a tercier szektor részesedésének növekedése volt a jellemző 1970 és 1993 között.

\section{Összefoglalás}

A délkelet-ázsiai ủjonnan iparosodó országok gazdasági növekedésének általános tendenciáit, az országok világkereskedelmi fontosságának, az export és a gazdasági szerkezet átalakulásának jellegzetességeit - 1970 és 1993 között - a következő tézisekben foglalhatjuk össze:

- Világgazdasági fontosságukat a legdinamikusabban a NIC országok növelték 1970 és 1993 között a világon; miközben a NIC I. csoport országai megötszörözték, a NIC II. vonalához tartozó országok pedig 2,4-szeresére növelték a világexportból való százalékos részesedésüket. 
- Ezzel párhuzamosan mindegyik országban jelentősen nőtt az egy före jutó export értéke, a világgazdasági recessziós időszakok hatása elsősorban az évi átlagos százalékos növekedési ráta csökkenésében mutatkozott.

- Dél-Korea kivételével - ahol a 90-es évek elejétől fokozatosan csökken - mindegyik országban nőtt a gazdasági növekedés exportfüggósége, ezt az egy forre jutó export és GNP közötti regressziós vizsgálatok is bizonyították.

- Az export áruszerkezetének változása (Hoover-index), párhuzamosan a gazdasági szerkezet átalakulásával azon NIC II. országokban volt a legnagyobb, ahol az exportösztönző, iparosító politikára csak a 70-es évek végétől kezdtek áttérni.

\section{Jegyzetek}

${ }^{1}$ Készult a 2173. számú, Dr. Bemek Ágnes által vezetett „A világgazdaság differenciálódási folyamatainak térszerkezeti vetülete" ${ }^{n}$. OTKA kutatási program keretében.

$2 \mathrm{Az}$ újonnan iparosodó országokat NIE=Newly Industrialized Economies ill NIC=Newly Industrialized Countries elnevezéssel is illetik.

${ }^{3}$ Az 1967-ben alakult ơnáló regionális szervezet (Fulöp-szigetek, Indonézia, Malajzia, Szingapúr, Thaifóld és Brunei alapitották) célja a szociảlis és kulturális egyưttmüködés és a gazdasági fejlestés gyorsítása mellett egy délkelet-ázsiai "kőzős piac" létrehozása volt. 1995-ben Vietnamot is felvették tagjaik kỏzé.

${ }^{4}$ Sajnos a tajvani adatok az ország speciális helyzetéböl adódóan az ENSZ ill. az IMF adatbáziséban nem szerepelnek. Mivel célunk az volt, hogy egységes adatbázis felhasználásával elemezzük az országok világgazdasági szerepkörének változását, ezért Tajvan a későbbiekben nem szerepel vizsgálatunkban.

${ }^{5}$ Forrás: Direction of Trade Stat. Yearbook (1970-1994)

${ }^{6} \mathrm{Az}$ exportkoefficiens értéke azt mutatja meg, hogy hány százalékban részesedett a kivitel a bruttó nemzeti termék értékébôl.

${ }^{7}$ Indonézia: 1970-11.99\%, 1993- 26.61\%, Fülöp-szigetek.: 1970-14.46\%, 1993-20.18\%

${ }^{8}$ SITC $=$ Standard International Trade Classification: 0 = élelmiszer, éló állat; $1=$ ital és dohány; $2=$ ásványi anyagok, kivéve fütőanyagok; 3= fütōanyagok; 4= állati és növényi zsiradék; $5=$ kémiai anyagok; 6alapanyagok; $7=$ gépgyárt́́s, szállitóeszközok; 8= egyéb iparcikkek; 9= nem besorolható áruk, tevékenységek.

9 1970-ben a 7-es kategória részesedései a következỏk voltak; Hongkong: 11.3\%, Dél-Korea: 7.37\%, Szingapúr: $10.9 \%$.

${ }^{10}$ Szingapúr esetében a 3-as kategória bár folyamatosan csökken -a köolajár csőkkenését követổen- még mindig $12.2 \%$.

"1 A teljesség igénye nélkal csak nćhány, mind a két ország gazdasági életében, exportjában jelentós terméket cmlítủnk meg: hajógyártás, elektronikai, számitástechnikai, telekommunikációs ipar stb.

12 1993-ban a0+1+2+3+4 kategóriák együttesen százalékos részesedése az összexportból: Indonézia 45.8\%, Malajzia 57.2\%, Fülöp-szigetek $20.5 \%$, Thaiföld $27.6 \%$ volt.

${ }^{13}$ Ezt talán az is megkőnnyíti, hogy Vietnamot 1995-ben felvették az ASEAN tagjai közé.

\section{Irodalom}

Ágh A. (1987) Globális kihivás. Magvető Kiado, Budapest.

Balassa B. (1990) Nemzetközi kereskedelem és gazdasági növekedés. Közgazdasági és Jogi Kiadó Budapest.

Cameron R. (1994) A világgazdaság rövid története. Maecenas Kiadó, Budapest.

Erdős T. (1986) Növekedési ütem, nōvekedési pálya. Közgazdasági és Jogi Kiadó, Budapest.

Hemádi A. (1985) A tóvol-keleti kihivás: Japán, a "négyek" és Kína a 80-as években. Közgazdasági és Jogi Kiadó, Budapest.

Kádár B. (1979) Szerkezeti változások a világgazdaságban. Közgazdasági és Jogi Kiadó, Budapest.

Kulessa M. (1990) The Newly Industrializing Economies of Asia. Springer-Verlag, Heidelberg

King A.-Schneider B. (1991) Az elsõ globális forradalom. Statiqum Kiadó, Budapest.

Kwan C. H. (1994) Economic Interdependence in the Asia-Pacific Region. Routledge, London

Simai M. (1985) Hatalom-technika-világgazdaság. Közgazdasági és Jogi Kiadó, Budapest. 
Simai M. (1992) A világgazdasági rend és az új multilaterializmus. Aula Kiadó, Budapest.

\section{Abstract}

A 1991 study of the Roman Club emphasised, as a "geo-strategic change", the appearance and development of three industrial and trading groups, blocks, namely the North American block, the EC countries and Japan with the NIE + ASEAN countries.

They placed a special emphasis on the fact that the countries which reacted in the most flexible and effective way to the fast changes in technology in the past twenty years were Japan and the NIE-NIC, also the ASEAN countries.

In our study, the south-east Asian region covers eight newly industrialised countries, namely Hongkong, South Korea, Singapore, Taiwan, the Philippines, Indonesia, Malaysia and Thailand.

The purpose of this study is to analyse the evolution of the role of these countries in the world economy and the growth in their importance in world trade, trying to find tendencies, general features and visible differences in the period 1970-1993. 